Special Issue of the 6th International Congress \& Exhibition (APMAS2016), Maslak, Istanbul, Turkey, June 1-3, 2016

\title{
The Effects of Austempering and Induction Hardening on the Wear Properties of Camshaft Made of Ductile Cast Iron
}

\author{
B. KARACA ${ }^{a, *}$ AND M. ŞiMŞiR ${ }^{b}$ \\ ${ }^{a}$ ESTAŞ Eksantrik San. ve Tic. A.Ş., 58060 Sivas, Turkey \\ ${ }^{b}$ Cumhuriyet University, Engineering Faculty, Department of Metallurgy and Materials Eng., 58100 Sivas, Turkey
}

\begin{abstract}
The aim of this study is to investigate the effects of heat austempering and induction hardening on the wear properties of GGG60 ductile cast iron for camshaft production. For this purpose, camshafts have been produced by sand mould casting method. Fe-Si-Mg alloy has been used for inoculation process to achieve iron nodulization. The casting has been done between $1410-1420^{\circ} \mathrm{C}$. The casted camshafts have been austenitized at two different temperatures $\left(800\right.$ and $\left.900^{\circ} \mathrm{C}\right)$ and time intervals $(60$ and $90 \mathrm{~min})$ under controlled furnace atmosphere. The austenitized camshafts have been quenched into the molten salt bath at $360^{\circ} \mathrm{C}$, held there for 90 min and then cooled in air. This way, austempering heat treatment has been applied. After that, surface hardening process was conducted using induction hardening machine with medium frequency. Microstructure of camshafts has been examined by optical methods and mechanical tests have been performed. Results show that austempering heat treatment increases the wear resistance of camshaft, compared to as-cast condition. Wear resistance of the camshaft increases with increasing austenitizing temperature, time and with induction hardening. The lowest weight loss of $0.62 \mathrm{mg}$ has been obtained for the induction hardened camshaft austenitized at $900{ }^{\circ} \mathrm{C}$ for $90 \mathrm{~min}$.
\end{abstract}

DOI: 10.12693/APhysPolA.131.448

PACS/topics: 46.55.+d, 62.20.Qp

\section{Introduction}

In production of camshafts for the engines casting and machining techniques are used. Today, due to many advantages, camshafts are produced from gray, nodular graphite-cast iron and also by machining of steel. Nodular cast iron (ductile iron) is more convenient in terms of production costs compared to machining production methods. At the same time, it is $10 \%$ lighter than steels. Austempered ductile iron (ADI), when compared with steel, has low material and production cost, low density, good processing ability and a high vibration damping ability. As a result of the superior properties, it is being used in many fields and became the subject of this study $[1,2]$. ADI is commonly used as structural material that should have a good wear resistance and tensile strength, in such applications as camshafts, which have an important task in engine and automotive industry. These advantages make ADI attractive in industrial applications [3, 4]. In $\mathrm{ADI}$, ausferrite (austenite + ferrite) matrix structure is formed during austempering process, which differs from bainitic structure being formed in steels. Therefore, it has different mechanical properties. When the literature is reviewed, it is noted that research on this subject has been in progress $[5,6]$. It is known from literature that the mechanical properties of ductile iron are improved after applying austempering heat treatment $[7,8]$. However, a study of the effect of induction hardening process

*corresponding author; e-mail: bahadir.karaca@estas.com.tr on the properties of ADI can not be found in the literature. The aim of this study is to investigate the effects of austempering and induction hardening on microstructure and wear properties of small sectioned camshaft.

\section{Materials and equipment}

\subsection{Materials and methods}

Sand mould was prepared for the camshaft casting. Melting of metal was conducted in induction furnaces. The chemical composition of metal was analyzed by a spectrometer and Atas thermal analysis equipment. Table I shows the chemical composition of cast iron used in camshaft production.

TABLE I

Chemical composition of casted camshaft.

\begin{tabular}{c|c|c|c|c|c|c|c|c}
\hline \hline $\mathrm{C}$ & $\mathrm{Si}$ & $\mathrm{Mn}$ & $\mathrm{P}$ & $\mathrm{S}$ & $\mathrm{Mg}$ & $\mathrm{Cr}$ & $\mathrm{Ni}$ & $\mathrm{Mo}$ \\
\hline 3.47 & 2.41 & 0.16 & 0.039 & 0.019 & 0.041 & 0.075 & 0.043 & 0.02 \\
\hline $\mathrm{Cu}$ & $\mathrm{Al}$ & $\mathrm{Ti}$ & $\mathrm{V}$ & $\mathrm{Nb}$ & $\mathrm{W}$ & $\mathrm{Co}$ & $\mathrm{Sn}$ & $\mathrm{Fe}$ \\
\hline 0.85 & 0.005 & 0.01 & 0.005 & 0.002 & 0.003 & 0.001 & 0.003 & Balance
\end{tabular}

Nodulizing process was carried out in the treatment crucible at temperatures between $1550-1570^{\circ} \mathrm{C}$. Fe-Si$\mathrm{Mg}$ alloy was used for nodulizing treatment. When liquid metal was poured into the casting crucible, Fe-Si-Ba-Ca$\mathrm{Al}$ alloy was added into poured metal for inoculation process. Camshaft casting process had taken 11-13 seconds at casting temperature of $1410-1420^{\circ} \mathrm{C}$. During casting, temperature of molten metal in the crucible was in the range of $1410 \pm 10^{\circ} \mathrm{C}$ and was controlled by a laser-type thermometer. 


\subsection{Heat treatment}

During the austempering heat treatments, cabin type furnace was used, based on electrical resistance heater, with highest temperature of $1100^{\circ} \mathrm{C}$, equipped with atmosphere and temperature control. After the camshafts were austenitized at 800 and $900^{\circ} \mathrm{C}$ for 60 and 90 minutes, they were rapidly austempered in salt bath $\left(50 \% \mathrm{KNO}_{3}+50 \% \mathrm{NaNO}_{3}\right)$ at $360{ }^{\circ} \mathrm{C}$ for 90 minutes. After that, camshafts were cooled in air to room temperature. When later, surface-hardening heat treatment was conducted for the samples of camshafts using medium frequency induction machine. Temperature control was achieved using thermal cameras. Surface microstructure was changed by induction heating during 3-4 s.

\subsection{Metallographic process}

Heat treated camshaft samples were made ready for microstructure investigation by standard metallographic methods (mounting, grinding, polishing) and then etching process was applied to the samples, by using $2 \%$ nital solution. Microstructure of the camshaft was examined under a Nikon MA200 optical microscop and analyzed by Clemex Vision Lite image analysis software. Percentage of nodularity, nodule size and number, volume fraction of graphite, ferrite and pearlite were measured.

\subsection{Mechanical tests}

Brinell hardness of core sections of camshafts, ascasted and austempered, was measured by applying $750 \mathrm{kgf}$ load using Instron Wolpert hardness measurement device. After induction surface hardening process, Rockwell hardness of each cam surfaces was measured by applying $150 \mathrm{kgf}$ load to the surface using the same Instron Wolpert hardness measurement device. Hardness test was carried out five times for different sections.

TABLE II

Wear test parameters.

\begin{tabular}{c|c|c}
\hline \hline Test parameters & Test 1 & Test 2 \\
\hline Wear ball bearing & $100 \mathrm{Cr} 6$ & $100 \mathrm{Cr} 6$ \\
Ball bearing hardness $[\mathrm{HRc}]$ & 65 & 65 \\
Ball bearing diameter $[\mathrm{mm}]$ & 5 & 5 \\
Nominal load $[\mathrm{N}]$ & 10 & 30 \\
Disc rotation speed $[\mathrm{rpm}]$ & 300 & 300 \\
Sliding speed $[\mathrm{m} / \mathrm{s}]$ & 0.095 & 0.095 \\
Sliding distance $[\mathrm{m}]$ & 500 & 500 \\
Test temperature $\left[{ }^{\circ} \mathrm{C}\right]$ & $\mathrm{RT}$ & $\mathrm{RT}$
\end{tabular}

For wear tests, wear test samples were prepared by taking cut views from cam sections on the as-casted camshafts and camshafts after heat treatment (austempering, austempering combined with induction hardening). UTS T10/20 pin-on-disc type tribometer was used for wear tests. Wear tests were conducted in accordance with ASTM Standard G99-05, with various loads, constant distance and at a constant RPM. Then, weight loss was measured using a sensitive balance and wear surfaces were examined by optical microscopy of either the sample or of the ball bearing used as wearing counterpart. Because ASTM G99-05 standard is based on the measurement of wear volume, wear of ball bearing was calculated by using a mathematical relationship and by direct measurement of volumetric loss. Wear test parameters used in this study are shown in Table II.

\section{Results and discussion}

\subsection{Microstructure}

Results of image analysis obtained by Clemex Vision Lite program are given in Table III. As seen in the Table III, percentage of nodularity, nodule count, nodule size, graphite, ferrite and pearlite volume ratios are close to those of GGG60 cast iron standard. This shows that the method implemented in camshaft production was correct and reliable.
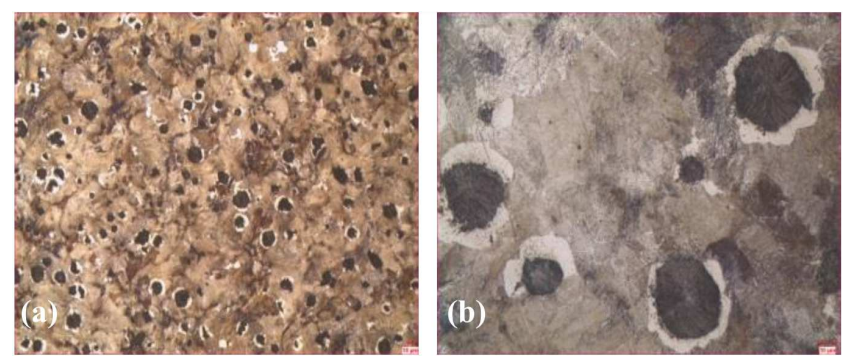

Fig. 1. The microstructure of the as-cast camshaft (a) $100 \times$, (b) $500 \times$.

Camshaft images presented in Fig. 1 show a perliticferritic microstructure. Black areas represent graphite nodules, white areas represent ferrite and grey areas represents perlite phase.
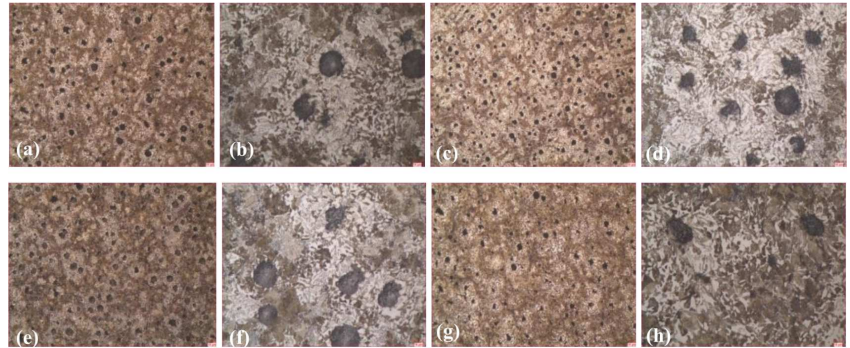

Fig. 2. Microstructures of austempered camshaft: austenitized at $800^{\circ} \mathrm{C}, 60 \min$ (a) $100 \times$, (b) $500 \times$; austenitized at $800^{\circ} \mathrm{C}, 90 \mathrm{~min}$ (c) $100 \times$, (d) $500 \times$; austenitized at $900^{\circ} \mathrm{C}, 60 \mathrm{~min}$ (e) $100 \times$, (f) $500 \times$ and austenitized at $900^{\circ} \mathrm{C}, 90 \mathrm{~min}(\mathrm{~g}) 100 \times$, (h) $500 \times$.

After austempering, the microstructure of camshafts corresponded to ausferrite (ferrite+austenite), see Fig. 2. It is observed that when austenitizing time was increased, the amount of austenite phase in the structure had also increased (Fig. 2c and d). With increasing austenitizing temperature, a more homogeneous ausferrit has 
been obtained (Fig. 2e and f). With increasing austenitizing temperature and time, the austenite phase was found to be more homogeneous (Fig. $2 \mathrm{~g}$ and $\mathrm{h}$ ).

Figure 3 shows the microstructure of the camshaft austenitized at $900^{\circ} \mathrm{C}, 90 \mathrm{~min}$ to which induction hardening was applied. It is seen that with induction hardening heat treatment, nodular graphite has not changed and the core of camshaft has still austenite-ferrite structure. Martensitic structure was found only in a layer 2.0 to $3.5 \mathrm{~mm}$ thick near the surface. In addition to this, there is untransformed residue austenite and partly needle-shaped ferrite in the matrix structures.
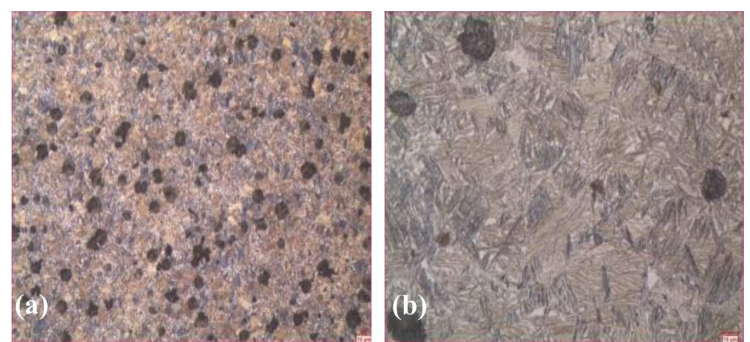

Fig. 3. Surface microstructure of induction hardened camshaft, austenitized at $900^{\circ} \mathrm{C}$ for $90 \mathrm{~min}$ (a) $100 \times$, (b) $500 \times$

Results of microstructural analysis.

\begin{tabular}{c|c|c|c|c|c|c}
\hline \hline & $\begin{array}{c}\text { Nodularity } \\
{[\%]}\end{array}$ & $\begin{array}{c}\text { Nodule count } \\
{\left[\mathrm{mm}^{-2}\right]}\end{array}$ & $\begin{array}{c}\text { Size of nodules } \\
{[\mu \mathrm{m}]}\end{array}$ & $\begin{array}{c}\text { Graphite vol. } \\
{[\%]}\end{array}$ & $\begin{array}{c}\text { Ferrite vol. } \\
{[\%]}\end{array}$ & $\begin{array}{c}\text { Perlite vol. } \\
{[\%]}\end{array}$ \\
\hline ASTM A247 & $\begin{array}{c}\text { Type 1/2 } \\
\text { Class 4-6 }\end{array}$ & $20-600$ & $100-10$ & - & $10-90$ & $\begin{array}{c}\text { Ferrite } \\
\text { Ferrite + Pearlite } \\
\text { Pearlite }\end{array}$ \\
\hline Measured & $\begin{array}{c}91 \\
\text { (Type 1/2) (Class 6-7) }\end{array}$ & 351 & 29.5 & 16.94 & 24.51 & $\begin{array}{c}58.55 \\
\text { Ferrite + Pearlite }\end{array}$
\end{tabular}

\subsection{Mechanical tests}

Because the core of camshaft cools more slowly than the surface, it is softer and is characterized using Brinell hardness. The hardness tests were conducted on the cross section of the cam, as shown in Fig. 4.

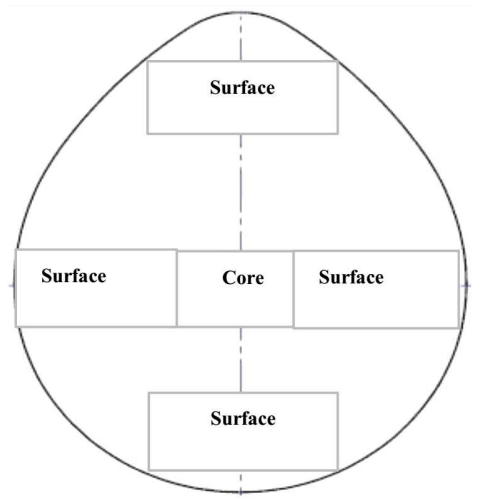

Fig. 4. The cross section of the camshaft, showing spots were hardness values were measured.

Figure $5 \mathrm{a}$ and $\mathrm{b}$ shows the core and surface hardness values, respectively, for samples processed at different heat treatment conditions. The results show that the core of austempered camshaft is $21 \%$ harder than that of ascasted camshaft. The core hardness of austempered and induction hardened camshaft is $33 \%$ higher than that of as-casted camshaft. This is due to the fact, that cooling

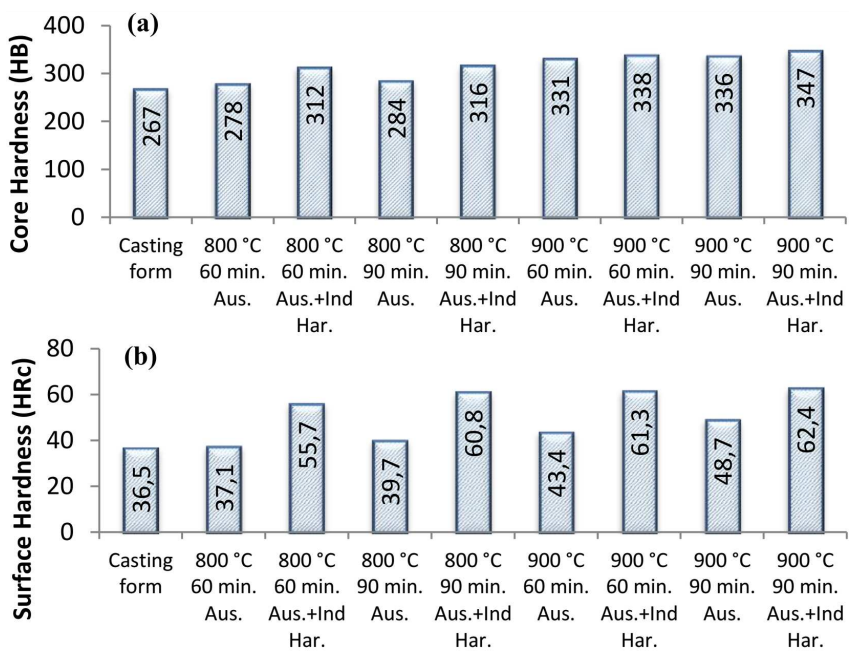

Fig. 5. The results of hardness measurements of the camshaft: (a) core hardness (HB), (b) surface hardness (HRc).

rate of core of the austempered camshaft and of induction hardened camshaft is higher than that of the camshaft in the as-cast condition. When their surface hardness values are compared, it is seen that their microstructures were formed differently. With induction hardening heat treatment, martensitic microstructure was obtained on the surface of the camshaft. The ausferritic microstructure was found in austempered camshaft and in the as-cast camshaft there was perlitic-ferritic microstructure. 
Three wear tests were conducted for each load $(10 \mathrm{~N}$ and $3 \mathrm{~N}$ ) and their average was calculated. Wear test results are shown in Fig. 6. As seen from results, when load increases, friction coefficient, weight loss in camshaft and ball bearing increase for all camshaft samples, as-cast, austempered and induction hardened. However, it is observed that weight loss is minimum in the austempered and induction hardened surface of camshaft. The reason for that increase in the surface hardness is the presence of martensite phase on the surface and ausferrite phase in the core. The surface hardness is lower and weight loss is much stronger in as-casted camshaft. Minimum abrasion quantity was found in the camshaft which was austempered and induction hardened and tested under $10 \mathrm{~N}$ load. Maximum weight loss was measured in the camshaft that was as-casted and tested under $30 \mathrm{~N}$ load. Maximum wear of the ball bearing under $30 \mathrm{~N}$ load was obtained in wear test of as-casted camshafts because of the high friction coefficient. Therefore, the amount of wear increases as the friction coefficient increases. The lowest coefficient of friction was found in the austempered and induction hardened camshaft test that was conducted under applied load of $10 \mathrm{~N}$.

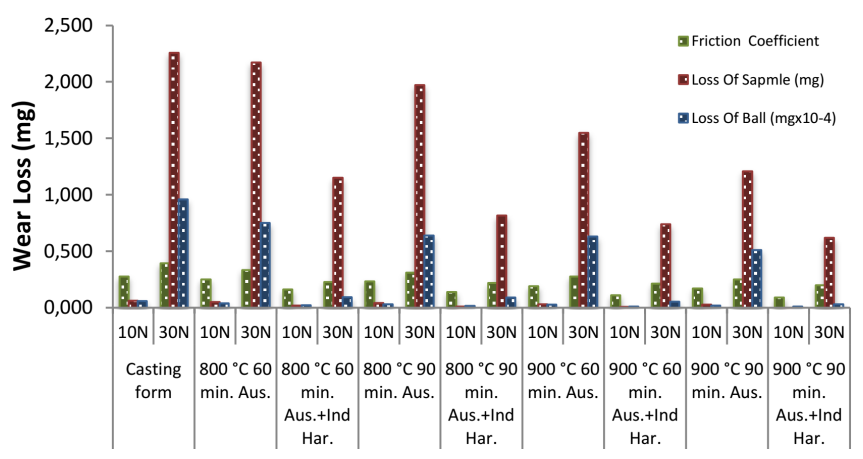

Fig. 6. Wear test results.

Optical microscope images of the samples are given in Fig. 7. The trace of wear on the sample tested under $10 \mathrm{~N}$ load and on the ball bearing are shown in Fig. 7a and in Fig. 7b, respectively. Wear trace width of the sample surface is relatively small. The gray-colored stripe seen in figure is the adhesion layer formed by coating the wear particles on the interface between the two wearing surfaces. It is generally known to be formed of oxides and contributes to the reduction of the friction coefficient, acting as a protective barrier. Wear particles can fall away, but some of them may hold on to the surface. Slight wearing trace is found on the surface of the ball bearing, see Fig. 7b. The trace of wear on the sample tested under load of $30 \mathrm{~N}$ is shown in Fig. 7c and the corresponding ball bearing is shown in Fig. $7 \mathrm{~d}$. It is possible to see the presence of adhesive layer and scratching trace together. The track width has expanded significantly. Friction and wear are seen to be more severe. There are abrasive wear marks on the surface of the ball bearing as well.

Optical microscope images of $900^{\circ} \mathrm{C}, 90 \mathrm{~min}$ austempered spheroid casting sample are given in Fig. 8. The trace
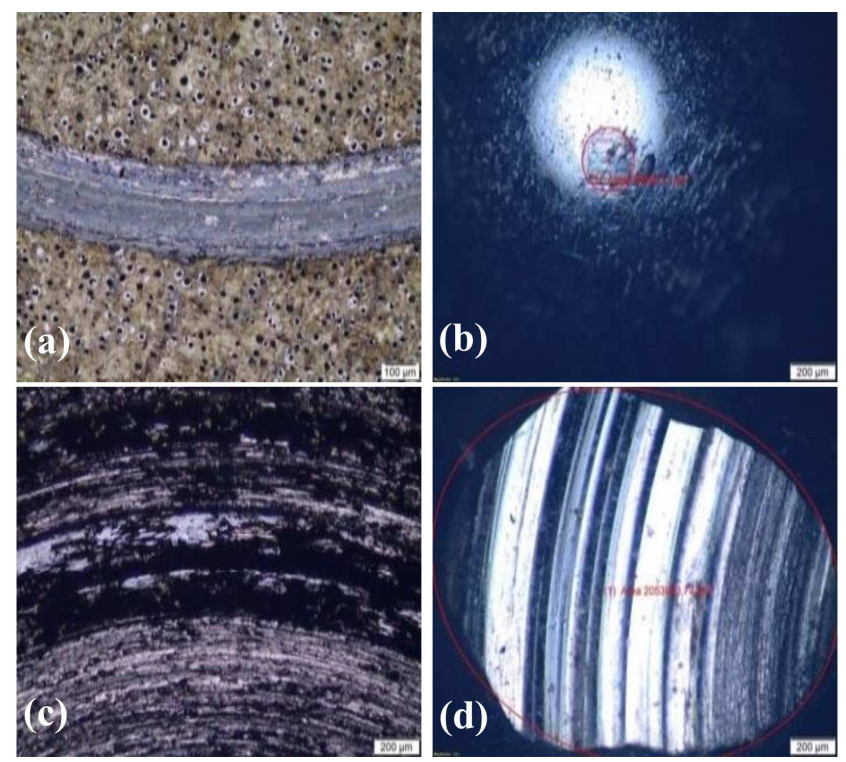

Fig. 7. The worn surfaces under as-cast condition, under the load of $10 \mathrm{~N}$ (a) sample, (b) ball bearing; and under load of $30 \mathrm{~N}$ (c) sample, (d) ball bearing.
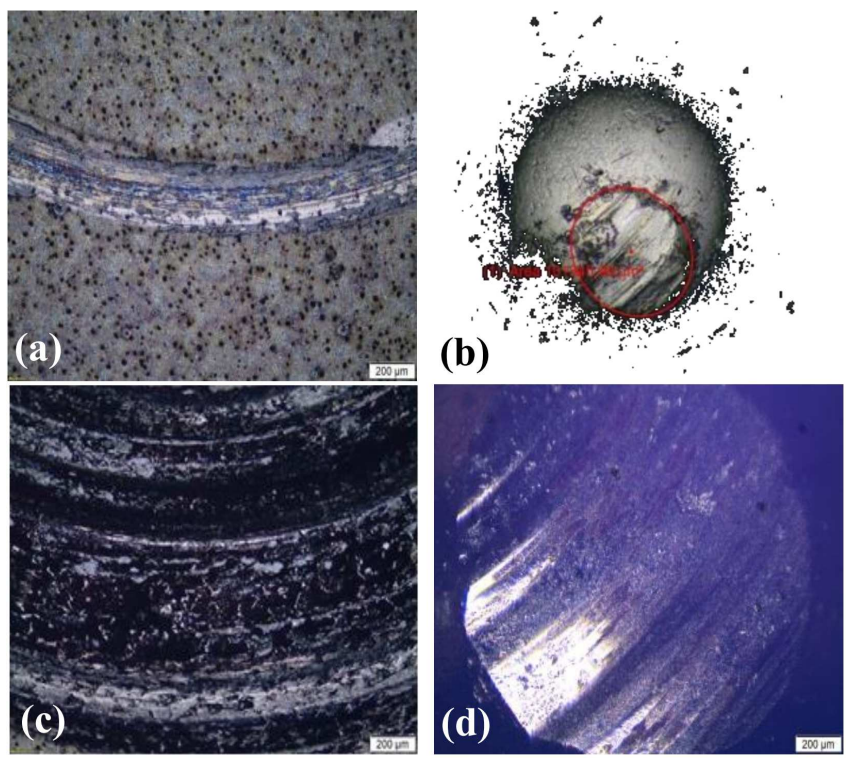

Fig. 8. The worn surfaces under austempering conditions, for applied load of $10 \mathrm{~N}$ (a) the sample, (b) ball bearing; and applied load of $30 \mathrm{~N}$ (c) the sample, (d) ball bearing.

of wear on the sample after abrasion test under $10 \mathrm{~N}$ load is shown in Fig. 8a and on ball bearing in Fig. 8b. Sample surface with adherent and abrasive wear marks shows a mixed wear characteristics. An image with abrasive wear marks, spread over a very small area, was captured on the ball bearing surface. After the abrasion test under $30 \mathrm{~N}$ load, on the sample surface, the abrasion has intensified. An image of simultaneous abrasive and adhesive wear marks is shown in Fig. 8c. Abrasive wear marks are intensively present (Fig. 8d) and the diameter of the worn out section is enlarged on the ball bearing surface. 
Optical microscope images of the austempered and induction hardened sample are given in Fig. 9. The trace of wear on the sample after abrasion test under $10 \mathrm{~N}$ load is shown in Fig. 9a and on the ball bearing in Fig. 9b. At the same time, there are adherent and abrasive wear marks on the sample surface. There are intense abrasive marks on the surface of the ball bearing. The marks on the sample surface and ball bearing after abrasion test under $30 \mathrm{~N}$ load are seen in Figs. 9c and d, respectively. The type of abrasion is the same as in the test under $10 \mathrm{~N}$ and there is a mix of abrasion and adhesive wear mechanisms, however mark width has increased due to intensified friction. In the same way, abrasive wear mechanism is seen on the surface of the ball and the wear trace diameter is increased.
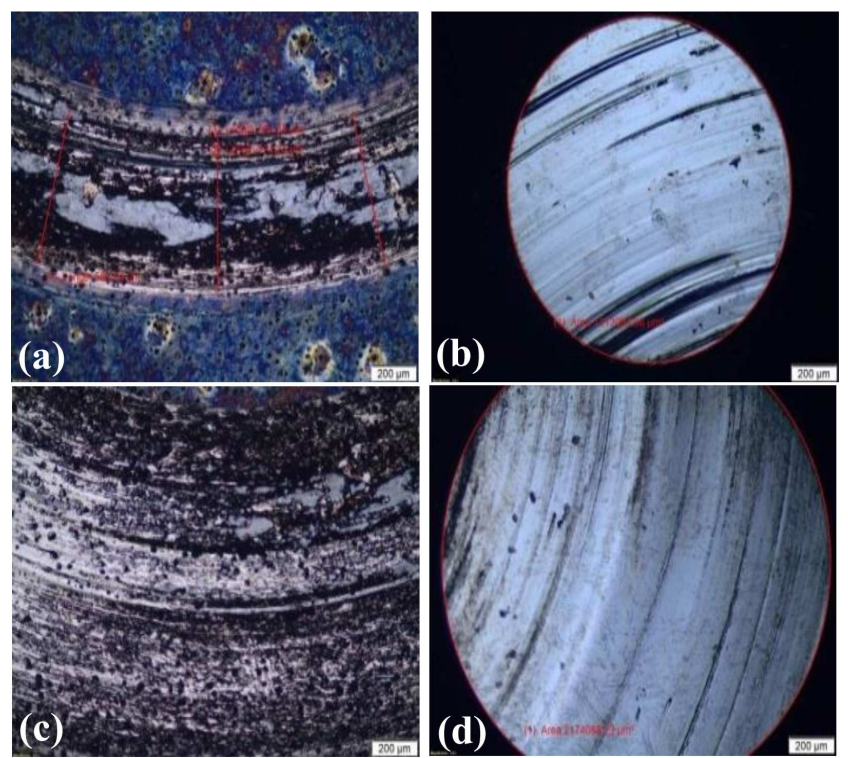

Fig. 9. The optical microscope images of abrasion surfaces of austempered and induction hardened camshaft under $10 \mathrm{~N}$ load (a) sample, (b) ball bearing; and under $30 \mathrm{~N}$ load (c) sample, (d) ball bearing.

\section{Conclusions}

In this study, the effects of austempering and austempering combined with induction hardening heat treatments on the wear and microstructure of camshafts made of ductile cast iron were investigated and the following results were obtained:

1. The microstructure of samples in the as-cast camshaft contains graphite nodules and ferritic-pearlitic matrix. Austempered camshaft samples microstructure contains ausferrite (austenite+ferrite).
The core of microstructure of camshaft produced using austempering combined with induction hardening contains nodule graphite and maintains its ausferrit microstructure. The surface microstructure of such camshaft consists of nodule graphite, fine martensite, some untransformed austenite and some needle ferrite.

2. Austempering process was applied to GGG60class nodular cast iron. The core hardness of nodular cast iron has increased from $258 \mathrm{HB}$ to $336 \mathrm{HB}$, surface hardness value from $34.8 \mathrm{HRc}$ to 48.7 HRc. After induction hardening heat treatment the core hardness value has increased from $336 \mathrm{HB}$ to $347 \mathrm{HB}$, surface hardness value has increased from $34.8 \mathrm{HRc}$ to $62.4 \mathrm{HRc}$.

3. When wear resistances of produced camshaft samples are compared, the wear resistance of the as-cast camshaft has increased by $45-50 \%$ after austempering heat treatment. After applying induction surface hardening heat treatment, the wear resistance of camshaft has increased by $75-85 \%$ with respect to wear resistance of as-cast camshaft.

4. While adhesive wear mechanism was seen under $10 \mathrm{~N}$ loads in as-cast camshaft, after increasing the applied load, wear mechanism has changed to abrasive wear. Wear mechanism for austempered and induction hardened camshafts is the abrasive wear mechanism, regardless of the applied load.

\section{References}

[1] J. Dodd, Mod. Casting 68, 60 (1978).

[2] A. Meena, Met. Progr. 128, 19 (2011).

[3] R. Harding, G. Gilbert, Br. Foundryman 79, 489 (1986).

[4] B. Çetin, H. Meco, K. Davut, J. Mater. Sci. 29, 2149 (2016).

[5] C. Labrecque, M. Gagné, Canadian Metallurgical Quarterly 37, 343 (1998).

[6] M. Yamanaka, R. Tamura, K. Inoue, JIM Volume 33, 543 (2009).

[7] B. Y. Lin, E.T. Chen, T.S. Lei, Journal of Materials Engineering and Performance 7, 407 (1998).

[8] B. Avishan, S. Yazdani, C. Vahid, AFS Trans. 95, 22 (2013). 